\title{
Can the mean platelet volume predict the mortality of patients with head trauma?
}

\author{
Bulent Ozdemir ${ }^{1}$, Ayhan Kanat ${ }^{2}$, Hizir Kazdal ${ }^{1}$, Osman Ersagun Batcik ${ }^{1}$, Vacide \\ Ozdemir $^{1}$, Yusuf Sulun ${ }^{3}$, and Ali Riza Guvercin ${ }^{4}$ \\ ${ }^{1}$ Recep Tayyip Erdoğan University \\ ${ }^{2}$ Affiliation not available \\ ${ }^{3}$ Mugla Sitki Kocman University Faculty of Science \\ ${ }^{4}$ Karadeniz Technical University
}

February 5, 2021

\begin{abstract}
Objective: Prediction of mortality in the patient of the intensive care unit is essential. It was aimed to study the mortality predictive value of mean platelet volume (MPV) in patients with severe head trauma. Study design: The mean platelet volumes were measured in patients with head injury managed intensive care unit between 1 December 2017 and 1 January 2019 at admission and exitus date. Methods: The main outcome variable was mortality due to the traumatic event of patients. 43 patients with head trauma admitted to the intensive care unit during the study period. 17 patients died (Group I), 26 survived (Group II). Results: There was not an association between MPV and mortality at admission. However, Cox regression analysis showed that late MPV (at exitus or discharged date), WBC at admission, and age increase the mortality rate 1,770, 1,202, 1,052 times, respectively. Conclusion: The present study shows that MPV may be a useful predictor of mortality in the patient with severe head trauma. More detailed studies are needed.
\end{abstract}

\section{Hosted file}

27 December 2020 MPV.edited.pdf available at https://authorea.com/users/393847/articles/ 507369-can-the-mean-platelet-volume-predict-the-mortality-of-patients-with-head-trauma

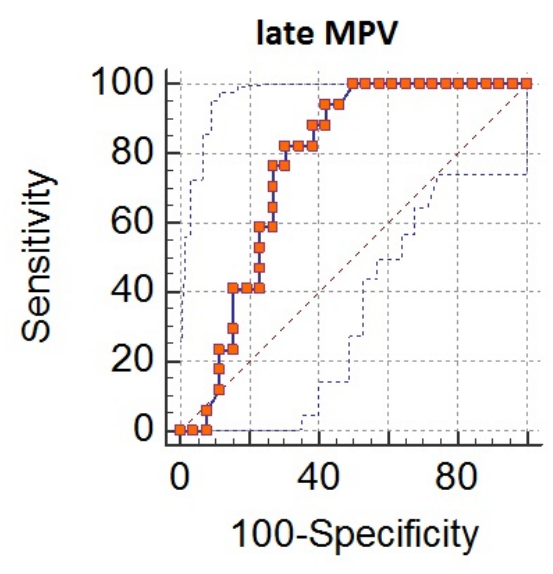




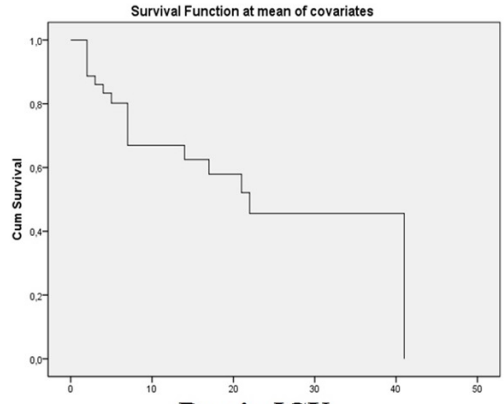

Day in ICU

\section{Hosted file}

table 1 tum hastalar.pdf available at https://authorea.com/users/393847/articles/507369-canthe-mean-platelet-volume-predict-the-mortality-of-patients-with-head-trauma

\section{Hosted file}

table2.pdf available at https://authorea.com/users/393847/articles/507369-can-the-meanplatelet-volume-predict-the-mortality-of-patients-with-head-trauma

\section{Hosted file}

TABLE3.pdf available at https://authorea.com/users/393847/articles/507369-can-the-meanplatelet-volume-predict-the-mortality-of-patients-with-head-trauma

\section{Hosted file}

table 4.pdf available at https://authorea.com/users/393847/articles/507369-can-the-meanplatelet-volume-predict-the-mortality-of-patients-with-head-trauma 